\title{
Production of high-acidity peach vinegar by improving the manufacturing process of "Dochobang"
}

\author{
Seong-hyun Jeon, Hyun-Ju Park, So-Young Kim, Soo-Hwan Yeo, Hee-Min Gwon* \\ Fermented Food Science Division, Department of Agrofood Resources, National Institute of Agricultural Science, \\ $R D A$, Wanju 55365, Korea
}

\section{전성현 · 박현주 · 김소영 · 여수환 · 권희민* \\ 농촌진흥청 국립농업과학원 농식품자원부 발효가공식품과}

“도초방” 의 제조 공정 개선을 통한 고산도 복숭아 식초 제조

\begin{abstract}
According to the method described in the ancient literature "Imwonsipyukji”', 'Dochobang' was mainly composed of lactic acid $(756.81 \mathrm{mg} / 100 \mathrm{~mL})$ and acetic acid $(473.66 \mathrm{mg} / 100 \mathrm{~mL})$ as the main organic acids on the 14th day of fermentation. The acidity of 'Dochobang' was $1.09 \%$, resulting in low marketability. Therefore, this study aimed to improve the manufacturing process of peach vinegar and optimize the conditions, including temperature and initial $\mathrm{pH}$, for producing high-acidity vinegar using fermented seeds. We first selected yeasts (Saccharomyces cerevisiae YM27) with excellent alcohol fermentation ability and acetic acid bacteria (Acetobacter oryzifermentans (KACC19301)) with remarkable acid-producing ability and used these in the process-improved two-stage fermentation. The experiment was conducted by 3 treatments of tepmerature $\left(20^{\circ} \mathrm{C}, 30^{\circ} \mathrm{C}\right.$ and $\left.35^{\circ} \mathrm{C}\right)$ and initial $\mathrm{pH}(3,4$ and 5$)$ for acetic acid fermentation. 'Dochobang' fermented alcohol and acetic acid at the same time by natural fermentation. on the other hand, peach wine starter and seed vinegar were added before each fermentation step to increase acetic acid production. Wines fermented at $25^{\circ} \mathrm{C}$ and $30^{\circ} \mathrm{C}$ were found to be $9 \%$ alcoholic on days sixth and nine days, respectively. Organic acid analysis revealed that the level of acetic acid in vinegar fermented at $\mathrm{pH} 4$ and $20^{\circ} \mathrm{C}$ increased steadily until day $14(6,171.3 \mathrm{mg} / 100 \mathrm{~mL})$. The acidity was $7 \%$ on the $21 \mathrm{st}$ day of fermentation. Furthermore, as the fermentation progressed, the umami and sourness of the peach vinegar increased. We expect that our findings could improve the quality of peach vinegar recorded in the old literature and can be used in small-scale agricultural companies.
\end{abstract}

Key words : ancient literature, high acidity, modern process, peach, vinegar

서 론

식초는 아주 오래전부터 음식의 맛을 내는 산미료로 사용 되었으며 이외에도 의학, 상처 소독, 미용 등 다양하게 이용 해 온 발효식품이다(Hwang 등, 2001; Shin과 Kang, 2012). 최근에는 노화방지, 혈당 조절, 간장 기능의 활성화와 같은 식초의 건강 기능성이 주목받기 시작하면서 원료와 발효 방
식을 달리한 식초에 대한 연구가 지속적으로 이루어지고 있 다(Jang 등, 2015; Jung 등, 2018a; Oh 등, 2015). 특히 과일 식초에 대한 연구로는 주로 저장성이 떨어지는 과일을 활용 하거나 발효 방식을 차별화하여 초산발효를 개선하는 등 다 양한 논의가 진행되었다(Kim, 1999; Lee 등, 1992). 본 실험 에서 사용한 개복숭아(Prunus persica Batsch var. davidiana Max.)는 돌복숭아, 산복숭아, 약복숭아 등으로 불리며, 전국

*Corresponding author. E-mail : vitamin89@korea.kr, Phone :+82-63-238-3611, Fax :+82-63-238-3843

Received 19 October 2020; Revised 27 November 2020; Accepted 01 December 2020.

Copyright (c) The Korean Society of Food Preservation.

This is an Open Access article distributed under the terms of the Creative Commons Attribution Non-Commercial License (http://creativecommons.org/licenses/by-nc/4.0) which permits unrestricted non-commercial use, distribution, and reproduction in any medium, provided the original work is properly cited. 
각지의 산이나 들에서 자생하는 앵도과의 낙엽 과수이다 (Jung 등, 2017a; Kim, 2004). 개복숭아는 과육의 향이 강하 여 술을 만들거나 청을 담가 먹기도 하며, 과실의 크기가 작아 식용보다는 주로 약용으로 이용되었다(Cho 등, 2012; Jung 등, 2017b). 또한 『본초강목』, 『동의보감』과 같은 옛 문헌에 서는 개복숭아가 혈액순환 촉진, 변비 개선, 고혈압 등에 효 능이 있다고 알려져 예로부터 민간요법으로 꾸준히 이용되어 왔다(Ahn, 1980; Kim, 2006; Kondo 등, 2001). 복숭아의 주 성분은 당분과 수분으로 이루어져 있고, 주석산, 사과산, 시 트르산과 같은 유기산이 함유되어 있으며, 알코올류, 알데히 드류 및 펙틴 등이 풍부하다(Kim 등, 2012). 복숭아 식초는 고문헌인 『임원십육지』에서만 찾아볼 수 있는 식초로 복숭아 를 항아리 속에서 1 주일간 숙성시킨 뒤 씨와 껍질을 제거하 고, 2주간 추가로 숙성시키는 방법으로 제조한다. 하지만 복 숭아는 정치 발효하여 식초를 제조할 경우, 발효 속도가 느리 고 수율이 낮다는 문제점이 보고된 바 있다(Cho 등, 2000; Lim과 Cha, 2010). 하지만 복숭아는 정치 발효하여 식초를 제조할 경우, 발효 속도가 느리고 수율이 낮다는 문제점이 보 고된 바 있다(Lim과 Cha, 2010). 따라서 본 연구에서는 조선 시대 농림의학 등 생활백과서인 『임원십육지』의 ‘도초방’에 기록된 전통 복숭아 식초의 제조공정을 현대적으로 개선하기 위해 적합한 발효 종균을 선발하고, 최적 발효조건을 확인하 였다. 또한 이를 이용하여 제조한 복숭아 식초의 품질 특성을 파악하고, 더 나아가 소규모 식초 제조업체에서 적용하고 활 용할 수 있도록 기초자료를 마련하고자 한다.

\section{재료 및 방법}

\section{고문헌 재현한 ‘도초방’ (복숭아 식초) 제조}

『임원십육지』에 기록된 방식대로 전통 복숭아 식초(도초

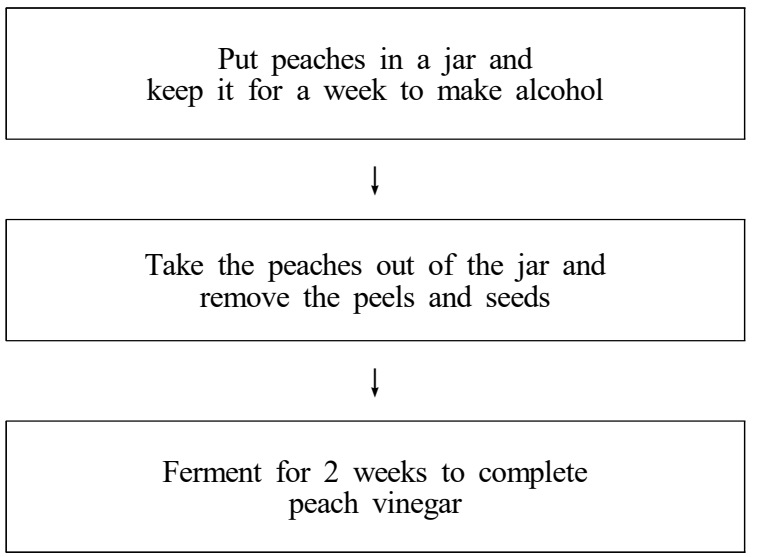

(A) Peach vinegar in "Imwonsipyukji』
방)를 제조하였다. 먼저 잘 익은 복숭아를 항아리에 담고 주 둥이를 밀봉하였고, 일주일 후 복숭아를 건진 후 껍질과 씨를 제거하고, 다시 밀봉한 뒤 2 주간 발효시켜 식초를 완성하였 다. 식초 제조 과정은 Fig. 1과 같으며, 발효기간 $(0,7,14,21$ 일)별 품질 특성(pH, 산도, 유기산)을 분석하였다.

\section{알코올 발효능 및 향이 우수한 효모 선발}

본 실험에서는 알코올 발효능이 우수한 효모를 선발하기 위해 국립농업과학원 발효자원실에서 분리 · 보관 중인 효모 22주(Table 1)을 대상으로 $\mathrm{CO}_{2}$ 생성량을 측정하고, sniffing test를 실시하였다. $\mathrm{CO}_{2}$ 생성량을 측정하기 위해 효모를 YPD broth에 접종하여 배양 $\left(30^{\circ} \mathrm{C}, 72\right.$ 시간)하면서 배양액의 감소 되는 무게 $(\mathrm{g})$ 를 24 시간마다 측정하였다. 또한 좋은 향을 내는 종균을 선발하기 위해 먼저 효모를 YPD broth $5 \mathrm{~mL}$ 에 100 $\mu \mathrm{L}$ 접종하여 2일간 진탕배양하였다. 이를 YPD agar 배지에 streaking하여 $30^{\circ} \mathrm{C}$ 에서 4 일간 배양한 균주와 배양하지 않은 YPD agar 배지(대조구)를 비교하여 sniffing test를 진행하고 30 분 간격으로 총 3 회 진행하였다.

\section{산 생성능이 우수한 초산균 선발}

산 생성능이 우수한 초산균을 선발하기 위해 국립농업과 학원 발효자원실에서 분리하여 보관 및 기탁 중인 초산균 8 종(Table 2)를 대상으로 실험을 진행하였다. 산생성능 정성적 평가방법으로 초산균 액체배지(yeast extract $0.5 \%$, glucose $0.5 \%$, glycerin $1 \%, \mathrm{MgSO}_{4} \cdot 7 \mathrm{H}_{2} \mathrm{O} 0.02 \%$, EtOH $6 \%$, acetic acid $1 \%$ )를 시험관에 $10 \mathrm{~mL}$ 씩 분주하여, 각 초산균을 $1 \mathrm{spot}$ 접종 후 $30^{\circ} \mathrm{C}$ 에서 72 시간 동안 $160 \mathrm{rpm}$ 으로 진탕 배양하였 다. 이어 초산균 선발용 고체배지(yeast extract $0.5 \%$, glucose $3 \%, \mathrm{CaCO}_{3} 1 \%$, EtOH $3 \%$, agar $2 \%$ )에 paper disk를 올리고

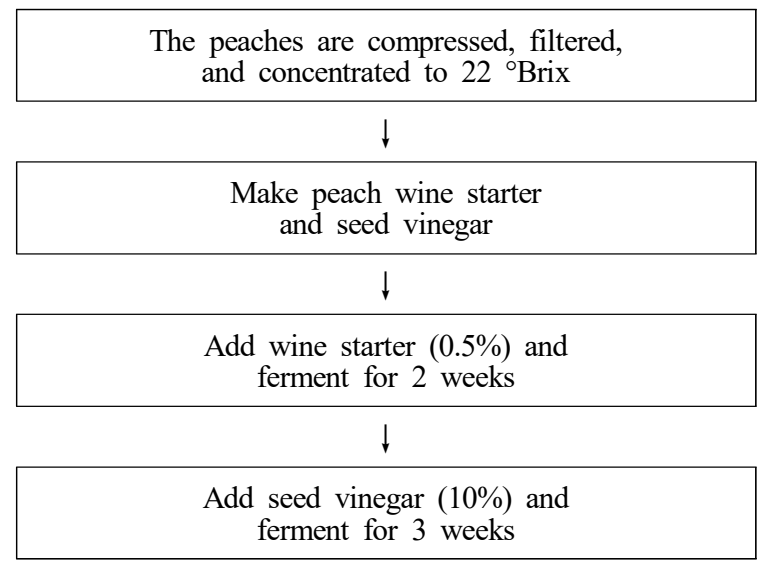

(B) Peach vinegar improved in this study

Fig. 1. Peach vinegar manufacturing process. 
Table 1. List of yeast strains used in this study

\begin{tabular}{|c|c|c|c|}
\hline No. & Strain & Species & Source \\
\hline 1 & YM22 & Saccharomyces cerevisiae & $\begin{array}{l}\text { 'Woorisul } \\
\text { oneul' }\end{array}$ \\
\hline 2 & YM24 & Saccharomyces cerevisiae & \multirow{2}{*}{$\begin{array}{l}\text { 'Ulgeum } \\
\text { makgeolli' }\end{array}$} \\
\hline 3 & YM25 & Saccharomyces cerevisiae & \\
\hline 4 & YM26 & Saccharomyces cerevisiae & \multirow{3}{*}{$\begin{array}{l}\text { 'Yuja } \\
\text { makgeolli' }\end{array}$} \\
\hline 5 & YM27 & Saccharomyces cerevisiae & \\
\hline 6 & YM28 & Saccharomyces cerevisiae & \\
\hline 7 & YM29 & Saccharomyces cerevisiae & \multirow{3}{*}{$\begin{array}{l}\text { 'Woorissal } \\
\text { wangmaesil } \\
\text { makgeolli' }\end{array}$} \\
\hline 8 & YM31 & Saccharomyces cerevisiae & \\
\hline 9 & YM32 & Saccharomyces cerevisiae & \\
\hline 10 & YM34 & Saccharomyces cerevisiae & \multirow{2}{*}{$\begin{array}{c}\text { 'Uiryeong } \\
\text { hwangsaegol } \\
\text { jeontong-gaju' }\end{array}$} \\
\hline 11 & YM35 & Saccharomyces cerevisiae & \\
\hline 12 & YM36 & Saccharomyces cerevisiae & \multirow{4}{*}{$\begin{array}{l}\text { 'Sulseam } \\
\text { Ehwaju' }\end{array}$} \\
\hline 13 & YM37 & Saccharomyces cerevisiae & \\
\hline 14 & YM38 & Saccharomyces cerevisiae & \\
\hline 15 & YM39 & Saccharomyces cerevisiae & \\
\hline 16 & YM40 & Saccharomyces cerevisiae & $\begin{array}{c}\text { 'Jukhyang } \\
\text { saengmakgeolli' }\end{array}$ \\
\hline 17 & YM42 & Saccharomyces cerevisiae & \multirow{2}{*}{$\begin{array}{l}\text { 'Hanbadang } \\
\text { takju' }\end{array}$} \\
\hline 18 & YM43 & Saccharomyces cerevisiae & \\
\hline 19 & YM44 & Saccharomyces cerevisiae & \multirow{4}{*}{$\begin{array}{l}\text { 'Cheonma } \\
\text { eyagi' }\end{array}$} \\
\hline 20 & YM45 & Saccharomyces cerevisiae & \\
\hline 21 & YM46 & Saccharomyces cerevisiae & \\
\hline 22 & YM47 & Saccharomyces cerevisiae & \\
\hline
\end{tabular}

Table 2. List of Acetobacter strains used in this study

\begin{tabular}{ccc}
\hline No. & Species & KACC $^{1)}$ \\
\hline 1 & Gluconobacter oxydans & KACC 11292 \\
2 & Gluconobacter thailandicus & KACC 16338 \\
3 & Acetobacter pasteurianus & KACC 17058 \\
4 & Komagataeibacter europaeus JY49 & KACC 17712 \\
5 & Acetobacter oryzifermentans & KACC 19301 \\
6 & Acetobacter pasteurianus A6 & KACC 92202P \\
7 & SLV-7 & - \\
8 & Y2019-1 & - \\
\hline
\end{tabular}

${ }^{1}$ KACC, Korean Agricultural Culture Collection.
초산균 배양액을 $50 \mu \mathrm{L}$ 씩 분주하여 $30^{\circ} \mathrm{C}$ 에서 72 시간 배양 후, 탄산칼슘 $\left(\mathrm{CaCO}_{3}, 1.0 \% \mathrm{v} / \mathrm{v}\right)$ 이 분해되어 형성된 투명환을 디지털 캘리퍼스(M500-180M, Hando-Midyo, Germany)를 이용하여 직경을 측정하였다. 산 생성능을 정량적으로 측정 하기 위해 에탄올 $(6 \%, \mathrm{v} / \mathrm{v})$ 과 초산 $(1 \%, \mathrm{v} / \mathrm{v})$ 이 함유된 초산균 액체배지를 제조하고, 각 초산균을 접종하여 배양액을 준비 하였다. 각 초산균 배양액을 이용한 종초를 제조하여 산도를 acetic acid(\%)로 환산하여 측정하였다. 먼저 전배양으로 초 산균 액체배지(yeast extract $0.5 \%$, glucose $0.5 \%$, glycerin $1 \%, \mathrm{MgSO}_{4} \cdot 7 \mathrm{H}_{2} \mathrm{O} 0.02 \%$, EtOH $6 \%$, acetic acid $1 \%$ )를 시 험관에 $50 \mathrm{~mL}$ 씩 분주한 후, 각각의 초산균을 접종하여 $30^{\circ} \mathrm{C}$ 에서 72 시간, $160 \mathrm{rpm}$ 으로 배양하였다. 이어서 산 생성능을 측정하기 위해 알코올 농도 $6.24 \%$ 로 제성한 막걸리 $500 \mathrm{~mL}$ 를 삼각 플라스크에 분주한 후, 전배양액 $50 \mathrm{~mL}$ 를 접종하여 $30^{\circ} \mathrm{C}$ 에서 정치 배양하였다. 산도 측정은 시료를 3 일 간격으 로 $1 \mathrm{~mL}$ 씩 채취한 후, 증류수 $9 \mathrm{~mL}$ 를 첨가하고 $\mathrm{pH}$ 가 8.3이 될 때까지 중화 적정하였고, $0.1 \mathrm{~N} \mathrm{NaOH}$ 용액의 적정 소비 량을 구하여 아래의 방정식으로 계산하였다.

Acidity $(\%)=\frac{\mathrm{V} \times \mathrm{F} \times \mathrm{A} \times \mathrm{D}}{\mathrm{S}} \times 100$

$\mathrm{V}$ : $0.1 \mathrm{~N} \mathrm{NaOH}$ 용액의 적정 소비량 $(\mathrm{mL})$

F: $0.1 \mathrm{~N} \mathrm{NaOH}$ 용액의 역가

A: $0.1 \mathrm{~N} \mathrm{NaOH}$ 용액 $1 \mathrm{~mL}$ 에 상당하는 유기산의 양 (초산 $=0.006)$

$\mathrm{D}$ : 희석배수

$\mathrm{S}$ : 시료 채취량 $(\mathrm{mL})$

\section{실험 재료 및 선발 균주}

식초 제조를 위한 원료인 개복숭아는 시중 마트에서 잘 익 은 것을 구매하여 사용하였다. 복숭아 발효주 제조에는 앞서 선발한 효모 Saccharomyces cerevisiae YM27을 사용하였고, 식초 제조에는 초산균 Acetobacter oryzifermentans(KACC 19301)를 사용하였다. 복숭아는 압착하고 착즙한 후 $22{ }^{\circ} \mathrm{Brix}$ 로 농축하였고 시료와 물을 $6: 4$ 비율로 혼합하여 사용하였다.

\section{공정 개선을 위한 복숭아 발효주 및 식초 제조}

전통방식의 복숭아 식초 제조 방식을 보완하고 현대적으 로 개선하기 위해 발효능이 우수한 균(효모, 초산균)을 선발 하고, 산 생성능을 높이기 위해 주모와 종초를 만들어 2단계 로 나누어 발효를 진행하였다. 발효 최적 조건을 찾기 위해 발효주를 온도별로, 식초를 온도, 초기 $\mathrm{pH}$ 별로 나누어 발효 시킨 후 품질 특성을 분석하였다. 초기 $\mathrm{pH}$ 를 조절하기 위해 
서 citric acid를 첨가하였으며, 공정 개선한 식초 제조 과정은 Fig. 1과 같다.

\section{주모 제조 및 복숭아 발효주 발효 및 품질 분석}

효모(YM27)를 YPD 배지에 각각 전배양 $\left(30^{\circ} \mathrm{C}, 160 \mathrm{rpm}\right.$, $48 \mathrm{~h}$ )한 후, 복숭아 농축액에 전배양한 효모 배양액을 $0.5 \%$ (v/v) 접종하고 $25^{\circ} \mathrm{C}$ 에서 72 시간 정치 배양하여 주모를 제조 하였다. 복숭아 농축액에 주모(YM27)를 $0.5 \%(\mathrm{v} / \mathrm{v})$ 씩 첨가하 고, 온도 $\left(18^{\circ} \mathrm{C}, 25^{\circ} \mathrm{C}, 30^{\circ} \mathrm{C}\right)$ 를 달리하여 발효시킨 후 발효기간 $(0,3,6,9,14$ 일)에 따라 복숭아 발효주의 품질 특성(당도, 알코올, 유리당, 유기산)을 분석하였다.

\section{종초 제조 및 복숭아 식초 발효 및 분석}

초산균(A. oryzifermentans KACC 19301)을 ALM 배지에 전배양 $\left(30^{\circ} \mathrm{C}, 160 \mathrm{rpm}, 48 \mathrm{hr}\right)$ 한 후, 알코올 농도가 $8 \%$ 내외 인 복숭아 발효주에 $10 \%(\mathrm{v} / \mathrm{v})$ 접종하고, $30^{\circ} \mathrm{C}$ 에서 산도가 $3-3.5 \%$ 가 될 때까지 정치 배양하였다. 알코올 농도가 $8 \%$ 내 외인 복숭아 발효주의 초기 $\mathrm{pH}$ 를 $3,4,5$ 가 되도록 식용 구연 산을 첨가하여 조정한 후, 사전에 만든 종초를 $10 \%(\mathrm{v} / \mathrm{v})$ 씩 넣고 온도 $\left(20^{\circ} \mathrm{C}, 30^{\circ} \mathrm{C}, 35^{\circ} \mathrm{C}\right)$ 를 달리하여 발효시킨 후 발효기 간 $(0,3,6,9,14,21$ 일)에 따라 복숭아 식초의 품질 특성(잔 존 알코올, 산도 및 유기산, 맛센서)을 분석하였다.

\section{당도 및 알코올 농도 측정}

당도는 굴절 당도계(Palette, Atago Co., Ltd., Tokyo, Japan)를 사용하여 실온에서 측정하였다. 알코올 농도는 시 료 $100 \mathrm{~mL}$ 와 증류수 $100 \mathrm{~mL}$ 를 실험관에 넣고 소포제를 2-3 방울 떨어뜨린 후, 알코올 증류기(VAP200, Gerhardt, Konigswinter, Germany)를 이용하여 증류액 $80 \mathrm{~mL}$ 를 받았 다. 다음으로 증류액에 증류수를 넣어 $100 \mathrm{~mL}$ 로 정용한 다 음 밀도 측정기(AT/DMA5000M, Anton Paar, Graz, Austria) 를 사용하여 분석하였다.

\section{$\mathrm{pH}$ 및 산도 측정}

복숭아 식초의 발효기간별 $\mathrm{pH}$ 를 확인하기 위해 식초의 여 과액을 $\mathrm{pH}$ meter(Orion 3 star, Thermo scientific Co., Waltham, MA, USA)를 이용하여 실온에서 측정하였고, 산 도는 시료 $1 \mathrm{~mL}$ 를 취하여 물을 $9 \mathrm{~mL}$ 첨가하고 $0.1 \mathrm{~N} \mathrm{NaOH}$ 를 이용하여 $\mathrm{pH}$ 8.3이 될 때까지 중화 적정하여 $0.1 \mathrm{~N} \mathrm{NaOH}$ 용액의 적정 소비량 $(\mathrm{mL})$ 을 구해 acetic acid 함량 $(\%)$ 으로 환 산하여 계산하였다.

\section{유리당 분석}

유리당은 HPLC(Waters 2695, Waters Co., Miliford, MA,
$\mathrm{USA}$ )를 이용하여 분석하였다. 시료를 $0.45 \mu \mathrm{m}$ PVDF membrane filter로 여과한 것을 시험용액으로 하였고, column은 Prevail carbohyderate $\mathrm{ES}(5 \mu \mathrm{m}, 4.6 \times 250 \mathrm{~mm})$ 를 사용하였으 며, mobile phase는 acetonitrile:water 혼합액(70:30, v/v), flow rate는 $1.0 \mathrm{~mL} / \mathrm{min}$, detector는 ELSD(Waters 2424, Waters Co.)를 사용하여 분석하였다.

\section{유리산 분석}

유기산은 HPLC(LC-20A, Shimadzu Co., Kyoto, Japan)를 이용하여 post column 방법으로 분석하였다. 유기산은 시료 $10 \mathrm{~mL}$ 를 취한 후 membrane filter $(0.2 \mu \mathrm{m})$ 로 여과하여 분석 에 사용하였고, 분석기기는 HPLC(LC-20A, Shimadzu Co.) 를 이용하여 post column 방법으로 분석하였다. 유기산 분석 용 컬럼은 TSKgel ODS-100V $5 \mu \mathrm{m}(4.6 \times 25 \mathrm{~cm}$, TOSOH Co, Japan)를 사용하였다. 이동상은 $8 \mathrm{mM}$ 과염소산(perchloric acid, Sigma Chemical Co., St. Louis, MO, USA)을 이용하 였으며, 유속은 $1.0 \mathrm{~mL} / \mathrm{min}$, 컬럼오븐의 온도는 $40^{\circ} \mathrm{C}$ 로 하였 다. 분리물은 반응용액 $0.2 \mathrm{mM}$ 브로모티몰블루(bromothymol blue, Sigma Chemical Co.), $15 \mathrm{mM}$ 인산수소이소듐 $\left(\mathrm{Na}_{2} \mathrm{HPO}_{4}\right.$, Sigma Chemical Co.), $7 \mathrm{mM}$ 수산화소듐과 반응 한 후 UV $440 \mathrm{~nm}$ 에서 검출하였다.

\section{전자혀를 이용한 복숭아 식초의 맛성분 분석}

식초가 가진 맛 성분의 패턴은 5 가지 맛 성분(AHS, CTS, $\mathrm{NMS}, \mathrm{PKS}, \mathrm{ANS})$ 와 2개의 reference에 관여하는 센서(SCS, $\mathrm{CPS})$ 와 1 개의 reference electrode $(\mathrm{Ag} / \mathrm{AgCl})$ 가 부착된 전자 혀(ASTREE II, Alpha MOS, Toulouse, France)를 이용하여 분석하였다. 이 중 $\mathrm{AHS}$ 는 신맛, $\mathrm{CTS}$ 는 짠맛, $\mathrm{NMS}$ 는 감칠 맛, $\mathrm{PKS}$ 는 단맛, $\mathrm{ANS}$ 는 쓴맛을 감지하고, $\mathrm{SCS}$ 와 $\mathrm{CPS}$ 는 standard로 사용되었다. 표준물질로 단맛은 sucrose(Sigma, Chemical Co.), 쓴맛은 quinine hydrochloride dihydrate (Sigma, Chemical Co.)를 사용하였다. 각 시료는 증류수로 100 배 희석하고 $0.45 \mu \mathrm{m}$ filter를 이용하여 여과하여 고형분 과 분석에 영향을 주는 미세한 입자들을 제거하였다. 또한 분 석 과정에서 시료 간 오염방지를 위해 다음 시료를 측정하기 전에 정제수를 이용하여 세척하였다. 시료는 전자혀 장비의 sampler에 장착한 다음 센서를 이용해 120 초간 접촉하여 맛 성분을 분석하였으며, 5 회간 반복 측정하였다.

\section{통계분석}

모든 실험은 3 회 반복하여 측정하였고, 그 결과는 평균값 \pm 표준편차로 나타내었다. 각 실험구 간의 유의성 $(\mathrm{p}<0.05)$ 을 검 증하기 위해 통계 분석을 하였으며, SAS(Statistical Analysis System program, SAS Institute., Cary, NC, USA)와 xlstat 프 
로그램을 이용하여 분산분석(analysis of variance, ANOVA) 한 후 Duncan's multiple range test로 다중비교를 실시하였다.

\section{결과 및 고찰}

\section{고문헌 재현한 ‘도초방’ (복숭아 식초) 제조}

『임원십육지』의 ‘도초방’에 기록된 방법으로 재현한 복숭 아 식초의 산도와 $\mathrm{pH}$ 변화는 Fig. 2 와 같다. 복숭아 식초의 $\mathrm{pH}$ 는 3.59-3.93, 산도는 0.65-1.09\%이며, 산도는 발효 14 일 차까지는 일정하게 유지되다가 21일차에는 약 $0.6 \%$ 로 감소 하였다(Fig. 2). 유기산 분석 결과는 Table 3과 같다. Acetic acid는 14 일차 $(473.66 \mathrm{mg} / 100 \mathrm{~mL})$ 까지는 증가하다가 21일 차 $(283.32 \mathrm{mg} / 100 \mathrm{~mL})$ 에는 감소하는 경향을 나타냈다. Acetobacter sp.는 초산을 재산화시킬 수 있는 TCA 회로를

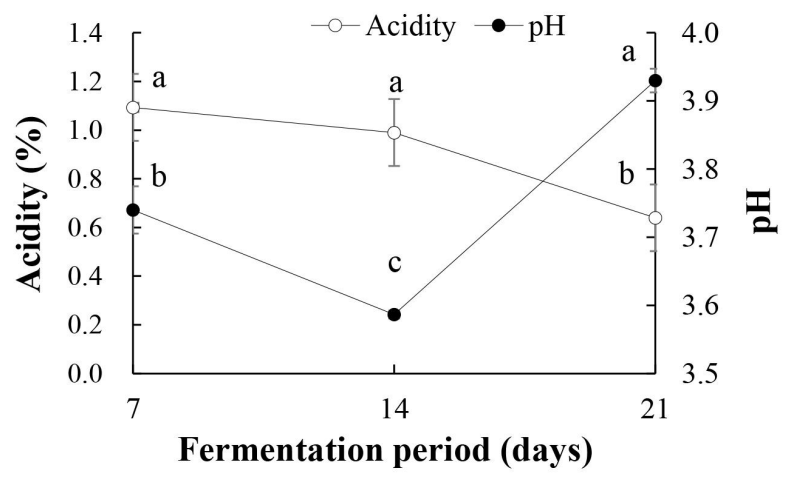

Fig. 2. Changes in acidity and $\mathrm{pH}$ of peach vinegars in

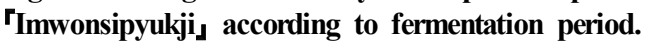

${ }^{1)}$ Values represent the mean \pm SD $(n=3)$. Means with different letters above a bar are significantly different at $\mathrm{p}<0.05$.

Table 3. Changes in organic acid content of traditionally fermented peach vinegar in 'Imwonsipyukji」 according to fermentation period (unit: $\mathrm{mg} / 100 \mathrm{~mL}$ )

\begin{tabular}{cccc}
\hline & \multicolumn{3}{c}{ Period (days) } \\
\cline { 2 - 4 } Organic acids & \multicolumn{1}{c}{14} & 21 \\
\hline Oxalic acid & $\mathrm{ND}^{1)}$ & $\mathrm{ND}$ & $\mathrm{ND}$ \\
Malic acid & $\mathrm{ND}$ & $\mathrm{ND}$ & $\mathrm{ND}$ \\
Lactic acid & 619.48 & 756.81 & 748.40 \\
Acetic acid & 389.39 & 473.66 & 283.32 \\
Citric acid & 0.36 & 7.72 & 26.22 \\
\hline Total & $1,009.23$ & $1,238.19$ & $1,057.94$ \\
\hline
\end{tabular}

${ }^{1)} \mathrm{ND}$, not detected.
가지고 있으며(Sim 등, 2001), 발효 14일차부터 acetic acid가 감소하기 시작하는 것은 초산균이 발효에 이용할 알코올이 부족해서 acetic acid를 다시 이산화탄소와 물로 분해하는 것 으로 생각된다. Lactic acid는 14 일차 $(756.86 \mathrm{mg} / 100 \mathrm{~mL})$ 까 지 증가하다가 21 일차 $(748.40 \mathrm{mg} / 100 \mathrm{~mL})$ 에는 소폭 감소하 였고, Citric acid는 21일차까지 꾸준히 증가하는 모습을 보였 다. Jung 등(2018b)의 연구에 따르면 천도복숭아로 제조한 식초의 유기산 분석 결과, acetic acid가 $3,242 \mathrm{mg} / 100 \mathrm{~mL}$ 로 가장 높았고, 다음으로 lactic acid, succinic acid, malic acid 의 순으로 나타났다. 그에 비해 본 실험에서 재현한 복숭아 식초는 lactic acid, acetic acid, citric acid 순으로 유기산 함량 이 높았으며, 전체적으로 유기산 함량이 낮았다. 특히 lactic acid가 acetic acid보다 더 많이 생성된 것을 볼 때 이는 과실 에 존재하는 각종 미생물을 이용하여 자연적으로 발효하는 전 통적인 방법의 특성상 오염에 취약하기 때문으로 생각된다.

\section{알코올 발효능이 우수한 효모 선발}

$\operatorname{Kim}$ 등(2013)의 실험에 따르면 효모는 알코올 발효를 통 해 포도당을 분해하여 $\mathrm{CO}_{2}$ 를 생성하며, 이 과정에서 효모마 다 생성하는 향기 성분은 다르게 나타난다. 본 실험의 결과로 대부분의 균주는 72시간에 비해 48시간 동안 $\mathrm{CO}_{2}$ 생산량이 높았다(Fig. 3). 특히 YM32는 총량이 $0.16 \mathrm{~g}$ 으로 가장 많았 고, 다음으로 YM22, YM25, YM27, YM31은 $0.14 \mathrm{~g}$ 으로 측 정되었다. Lee 등(2010)의 보고에 따르면 식초의 품질 특성 은 효모의 종류보다 발효 방법에 차이가 더 큰 것으로 나타났 으나, 향후 숙성 과정에서 향기 성분이나 관능적 특성에 영향 을 줄 수 있다고 하였다. 본 실험에서는 sniffing test를 통해 향이 좋은 효모를 선발하였고, 그 결과는 Table 4 와 같다. $\mathrm{YM} 22$ 는 달콤한 향을 냈고, YM27에서는 포도향, YM31과 $\mathrm{YM} 35$ 는 고소한 향, $\mathrm{YM} 38$ 은 바나나향, $\mathrm{YM} 39$ 와 $\mathrm{YM} 40$ 은 과일향, YM46과 YM47은 꽃향을 냈다. 반면에 YM24와 YM26에서는 에탄올 향, YM36과 YM37은 불쾌취가 났으 며, YM44는 가스 냄새가 났다. 그 후 30 분, 1 시간 뒤에 다시 진행한 2회차, 3 회차 sniffing test에서 대부분의 균주는 특이 취를 내지 않았다. 따라서 $\mathrm{CO}_{2}$ 생성량이 우수하고 과일향을 내는 S. cerevisiae YM27을 식초 제조를 위한 효모로 선발하 였다.

\section{산 생성능이 우수한 초산균 선발}

산 생성능을 정성적으로 알아보기 위해 초산균을 탄산칼 슘 $\left(\mathrm{CaCO}_{3}\right)$ 이 첨가된 고체 배지에 배양하였다. 초산균이 생 성한 초산은 탄산칼슘을 분해하는데(Asai와 Shoda, 1958), 탄산칼슘을 첨가하여 불투명해진 배지에 초산균이 자라면서 탄산칼슘이 분해되고 집락의 주위가 투명해진다. 이를 이용하 


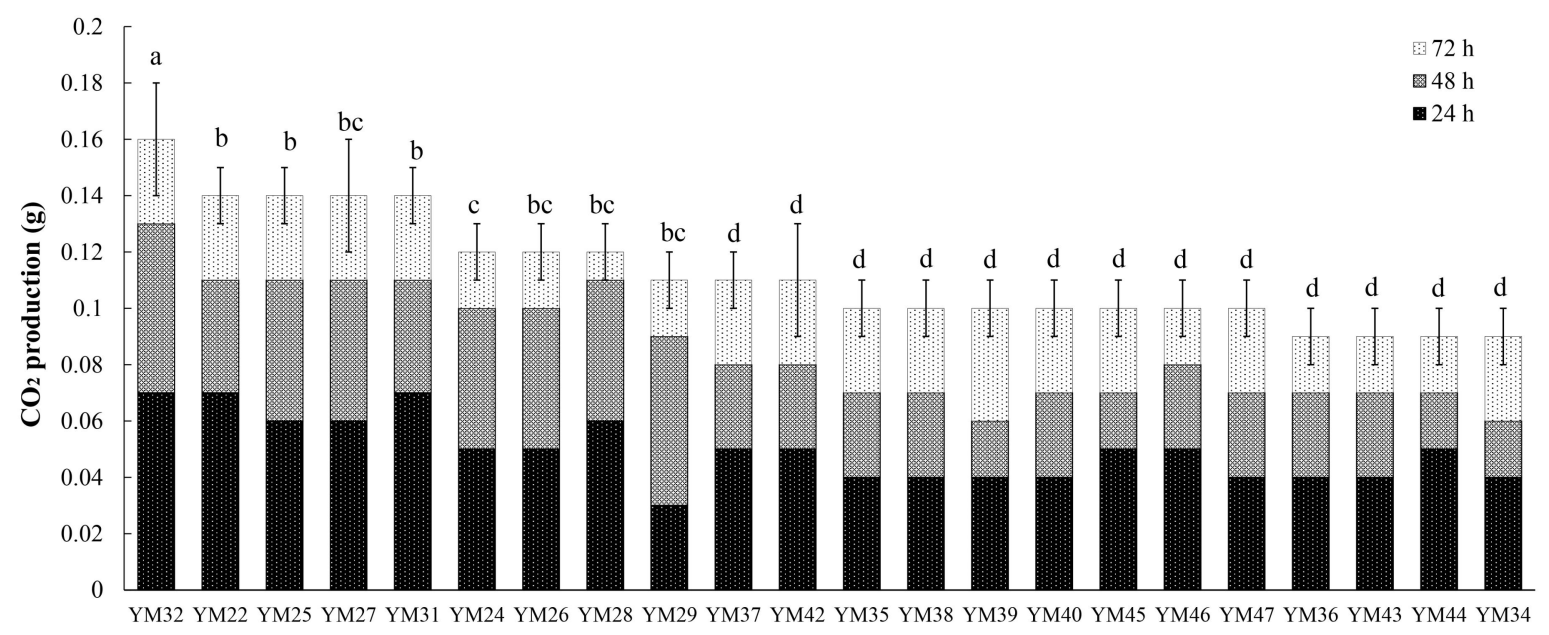

Fig. 3. $\mathrm{CO}_{2}$ production during fermentation by yeasts.

${ }^{1)}$ Values represent the mean $\pm \mathrm{SD}(\mathrm{n}=3$ ). Means with different letters above a bar are significantly different at $\mathrm{p}<0.05$.

Table 4. Sniffing test to select strains for alcohol fermentation

\begin{tabular}{|c|c|c|c|}
\hline Yeast strain & $1 \mathrm{st}$ & 2nd & $3 \mathrm{rd}$ \\
\hline YM22 & Sweet & - & - \\
\hline YM24 & Ethanol & Ethanol & - \\
\hline YM25 & - & - & - \\
\hline YM26 & Ethanol & - & - \\
\hline YM27 & Grape & Ethanol & Ethanol \\
\hline YM28 & - & - & - \\
\hline YM29 & - & - & - \\
\hline YM31 & Savory & - & - \\
\hline YM32 & - & - & - \\
\hline YM34 & - & - & - \\
\hline YM35 & Savory & - & - \\
\hline YM36 & Off-flavor & - & - \\
\hline YM37 & Off-flavor & - & - \\
\hline YM38 & Banana & - & - \\
\hline YM39 & Fruit & Ethanol & - \\
\hline YM40 & Fruit & - & - \\
\hline YM42 & - & - & - \\
\hline YM43 & - & - & - \\
\hline YM44 & Gas & - & - \\
\hline YM45 & - & - & - \\
\hline YM46 & Flower & - & - \\
\hline YM47 & Flower & - & - \\
\hline
\end{tabular}

여 투명환의 직경을 측정함으로써 산 생성능을 파악하였다. 실험에 이용된 8 주의 초산균 중 투명환이 $30 \mathrm{~mm}$ 이상으로 측정된 초산균은 3종(Acetobacter pasteurianus; Acetobacter oryzifermentans, SLV-7)이며, $20 \mathrm{~mm}$ 이상은 3종(Gluconobacter thailandicus, Komagataeibacter europaeus, Y2019-1), $10 \mathrm{~mm}$ 이상은 Gluconobacter oxydans로 나타났다. 또한 10 $\mathrm{mm}$ 이하로 측정된 균주는 Acetobacter pasteurianus A6이었 다(Fig. 4). 산 생성능을 정량적으로 평가하기 위해 종초로 막 걸리를 접종하여 산도의 변화를 측정하였으며, 발효 0 일차에 측정된 산도인 $0.66 \%$ 와 발효종료 시점인 9일차의 결과를 비 교함으로써 각 초산균이 나타내는 산 생성능을 확인하였다 (Table 5). 산 생성능이 가장 높게 나타난 A. oryzifermentans 는 9 일차에 $7.18 \%$ 로 측정되었으며, 다음으로 SLV-7이 $6.00 \%$ 로 높게 나타났다. 따라서 산 생성능이 가장 높은 초산 균 A. oryzifermentans를 식초 제조를 위한 초산균으로 선발 하였다.

\section{당도, 알코올 농도 변화}

온도에 따른 복숭아 발효주의 당도, 알코올 농도를 측정한 결과, $18^{\circ} \mathrm{C}$ 에서는 9 일차에 알코올 농도가 $7.5 \%$ 에 도달한 반 면, $25^{\circ} \mathrm{C}$ 에서는 $9.1 \%, 30^{\circ} \mathrm{C}$ 에서는 $9.7 \%$ 이었다(Fig. 5). Cho 등(2000)의 연구에서 효모와 초산균을 동시에 첨가하는 병행 복발효 방법으로 $21^{\circ} \mathrm{Brix}$ 복숭아 과즙을 원료로 $18-22^{\circ} \mathrm{C}$ 온 도 조건에서 식초를 제조한 결과, 최대 알코올 농도가 8 일차 에 $9.8 \%$ 를 나타내었다. 이는 단행복발효를 통해 제조한 복숭 아 와인의 9 일차 알코올 농도와 유사하였으며, 복숭아 과즙의 초기 당도가 비슷하기 때문에 최종적으로 알코올 농도가 비슷 한 것으로 판단된다. 본 실험에서 알코올 발효 온도가 $25^{\circ} \mathrm{C}$ 와 


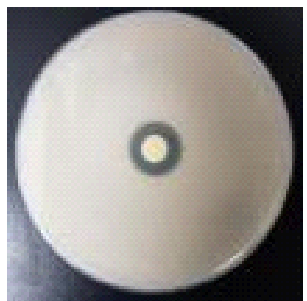

G. oxydans

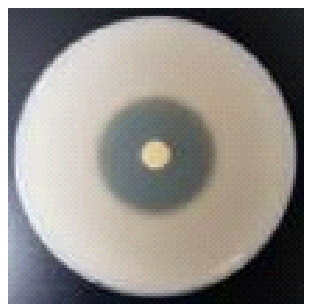

A. oryzifermentans

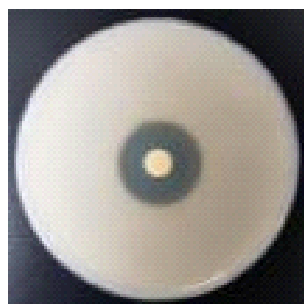

G. thailandicus

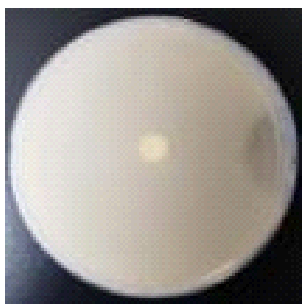

A. pasteurianus A6

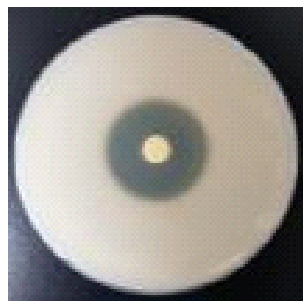

A. pasteurianus

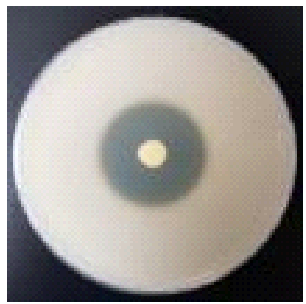

SLV-7

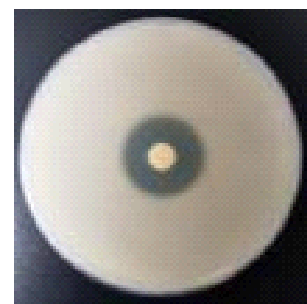

K. europaeus JY49

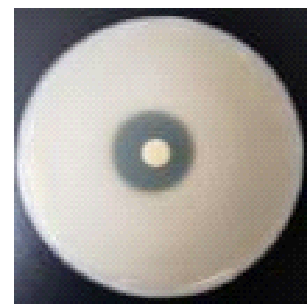

Y2019-1

Fig. 4. Qualitative evaluation to assess the acid production ability.

Table 5. Quantitative evaluation to assess the acid production ability of acetic acid bacteria

\begin{tabular}{|c|c|c|c|c|}
\hline \multirow{2}{*}{ Species } & \multicolumn{4}{|c|}{ Period (days, \%) } \\
\hline & 0 & 3 & 6 & 9 \\
\hline G. oxydans & $0.66 \pm 0.12^{1 \mathrm{a} 2)}$ & $0.74 \pm 0.09^{c}$ & $1.28 \pm 0.03^{\mathrm{d}}$ & $3.26 \pm 0.03^{\mathrm{d}}$ \\
\hline G. thailandicus & $0.66 \pm 0.12^{\mathrm{a}}$ & $0.70 \pm 0.03^{\mathrm{c}}$ & $1.74 \pm 0.06^{\mathrm{b}}$ & $3.02 \pm 0.03^{\mathrm{f}}$ \\
\hline A. pasteurianus & $0.66 \pm 0.12^{\mathrm{a}}$ & $0.68 \pm 0.03^{\mathrm{c}}$ & $1.46 \pm 0.03^{\mathrm{c}}$ & $3.12 \pm 0.00^{\mathrm{e}}$ \\
\hline K. europaeus JY49 & $0.66 \pm 0.12^{\mathrm{a}}$ & $0.76 \pm 0.03^{\mathrm{c}}$ & $1.28 \pm 0.03^{\mathrm{d}}$ & $3.02 \pm 0.03^{f}$ \\
\hline A. oryzifermentans & $0.66 \pm 0.12^{\mathrm{a}}$ & $1.90 \pm 0.03^{\mathrm{b}}$ & $4.18 \pm 0.09^{\mathrm{a}}$ & $7.18 \pm 0.07^{\mathrm{a}}$ \\
\hline A. pasteurianus A6 & $0.66 \pm 0.12^{\mathrm{a}}$ & $0.74 \pm 0.03^{\mathrm{c}}$ & $1.48 \pm 0.03^{\mathrm{c}}$ & $2.80 \pm 0.03^{\mathrm{g}}$ \\
\hline SLV-7 & $0.66 \pm 0.12^{\mathrm{a}}$ & $2.00 \pm 0.09^{\mathrm{a}}$ & $4.18 \pm 0.03^{\mathrm{a}}$ & $6.00 \pm 0.06^{\mathrm{b}}$ \\
\hline Y2019-1 & $0.66 \pm 0.12^{\mathrm{a}}$ & $0.68 \pm 0.03^{\mathrm{c}}$ & $1.10 \pm 0.03^{\mathrm{e}}$ & $3.44 \pm 0.03^{\mathrm{c}}$ \\
\hline
\end{tabular}

${ }^{1)}$ Data values were expressed as mean $\pm \mathrm{SD}$ of triplicate determinations.

${ }^{2}$ Values followed by the same letter are not statistically different by Duncan's multiple range test $(\mathrm{p}<0.05)$.
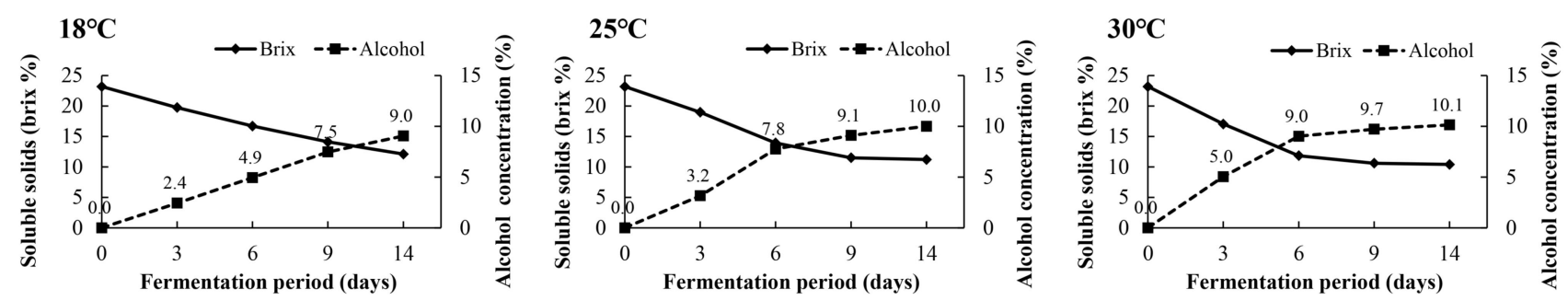

Fig. 5. Changes in soluble solids and alcohol concentration of peach wine during fermentation period at various temperature. 
$30^{\circ} \mathrm{C}$ 일 때, 14 일차에 생성된 최종 알코올의 함량은 비슷하였으 나, 경제성을 고려하여 알코올 발효를 위한 최적 온도로 $25^{\circ} \mathrm{C}$ 를 설정하였다.

\section{유리당 함량 변화}

Park 등(2017)의 연구에 따르면 포도 발효주의 유리당 함 량은 모든 처리구에서 발효 기간이 경과할수록 감소하는 모 습을 보였고, 발효 10 일차에는 glucose, fructose, sucrose 대 부분이 소진되어 발효가 완료되었다. 본 실험에서 복숭아 발 효주의 유리당 분석 결과, glucose는 $18^{\circ} \mathrm{C}$ 에서는 3 일차 이후 부터 꾸준히 증가하였고, $25^{\circ} \mathrm{C}$ 에서는 6 일차까지 증가하다가 그 이후로 서서히 감소하였으며, $30^{\circ} \mathrm{C}$ 에서는 9 일차까지 증가 하다가 그 이후부터 감소하는 모습을 보였다. Jain 등(2011) 의 연구에 따르면 S. cerevisiae는 에탄올 발효 시 sucrose의 $2-3 \%$ 를 glycerol로 전환한다고 보고된 것과 같이 발효 초기 에는 온도처리와 관계없이 sucrose의 분해로 glucose가 점차 증가하였고, 효모에 의해 발효가 원활히 진행되는 온도인 25 , $30^{\circ} \mathrm{C}$ 에서 각각 발효 6 일, 9 일차에 glucose가 급격히 소모되어 glucose가 감소하는 경향을 보였다. 그리고 두 온도처리에 비 해 발효가 느린 $18^{\circ} \mathrm{C}$ 에서는 발효 기간이 길어질수록 glucose 함량이 증가하였는데, 이는 sucrose 분해와 더불어 복숭아 원 료에 많이 포함된 펙틴(pectin)이 분해된 것으로 생각된다 (Fig. 6). Oh 등(1998)의 연구에서도 세포벽 구성성분인 펙틴 질이 분해되어 중성당으로 분해되거나, 저분자화되어 수용화
된다는 연구 결과와 유사하였다. 한편, fructose는 모든 실험 구에서 3 일차까지 증가하다가 그 이후부터는 감소하였고, sucrose는 모든 실험구에서 발효 3 일 이후 거의 다 소모되었 다. Rho 등(2008)의 보고에 따르면 알코올 발효에 의해 생성 되는 glycerol은 포도주를 부드럽게 만들어 쓴맛이나 완화해 주며, 복숭아 발효주의 glycerol 함량은 발효가 진행될수록 증가하는 경향을 보였고, 특히 $25^{\circ} \mathrm{C}$ 에서 발효시킨 복숭아주 는 발효 14 일차에 $5,786.79 \mathrm{ppm}$ 으로 가장 높게 나타났다.

\section{$\mathrm{pH}$, 알코올, 산도 변화}

복숭아 발효주에 초산균 A. oryzifermentans(KACC19301) 를 접종하고, 온도와 초기 $\mathrm{pH}$ 를 각각 달리하여 복숭아 식초의 $\mathrm{pH}$ 변화(Fig. 7)와 알코올 및 산도 변화를 측정하였다(Fig. 8). 그 결과, 전체적으로 초산발효가 활발히 이루어진 시료는 산도는 증가하고 $\mathrm{pH}$ 는 감소하는 경향을 보였다. 또한 초기 $\mathrm{pH} 3,30^{\circ} \mathrm{C}$ 조건에서 발효된 식초는 21 차에 산도가 0 일차보 다 $6.6 \%$ 증가하여 가장 높은 산도 증가량을 보였고, 다음으 로는 초기 $\mathrm{pH} 4,20^{\circ} \mathrm{C}$ 조건에서 발효된 식초는 산도가 $6.1 \%$ 증가한 것을 알 수 있었다. 21 일차에 초기 $\mathrm{pH} 3$ 의 $20^{\circ} \mathrm{C}$ 와 $30^{\circ} \mathrm{C}$ 조건에서 배양한 식초의 산도는 $9 \%$ 이상으로 높게 나타났는 데 이는 $\mathrm{pH}$ 조절을 하기 위해 첨가된 citric acid의 영향인 것으로 보인다. 초산균 A. oryzifermentans(KACC19301)은 $20^{\circ} \mathrm{C}$ 와 $30^{\circ} \mathrm{C}$ 인 온도 조건에서 초산발효가 원활히 이루어졌 으며 뛰어난 온도적응성을 보여주었다. 초기 $\mathrm{pH}$ 4로 설정한
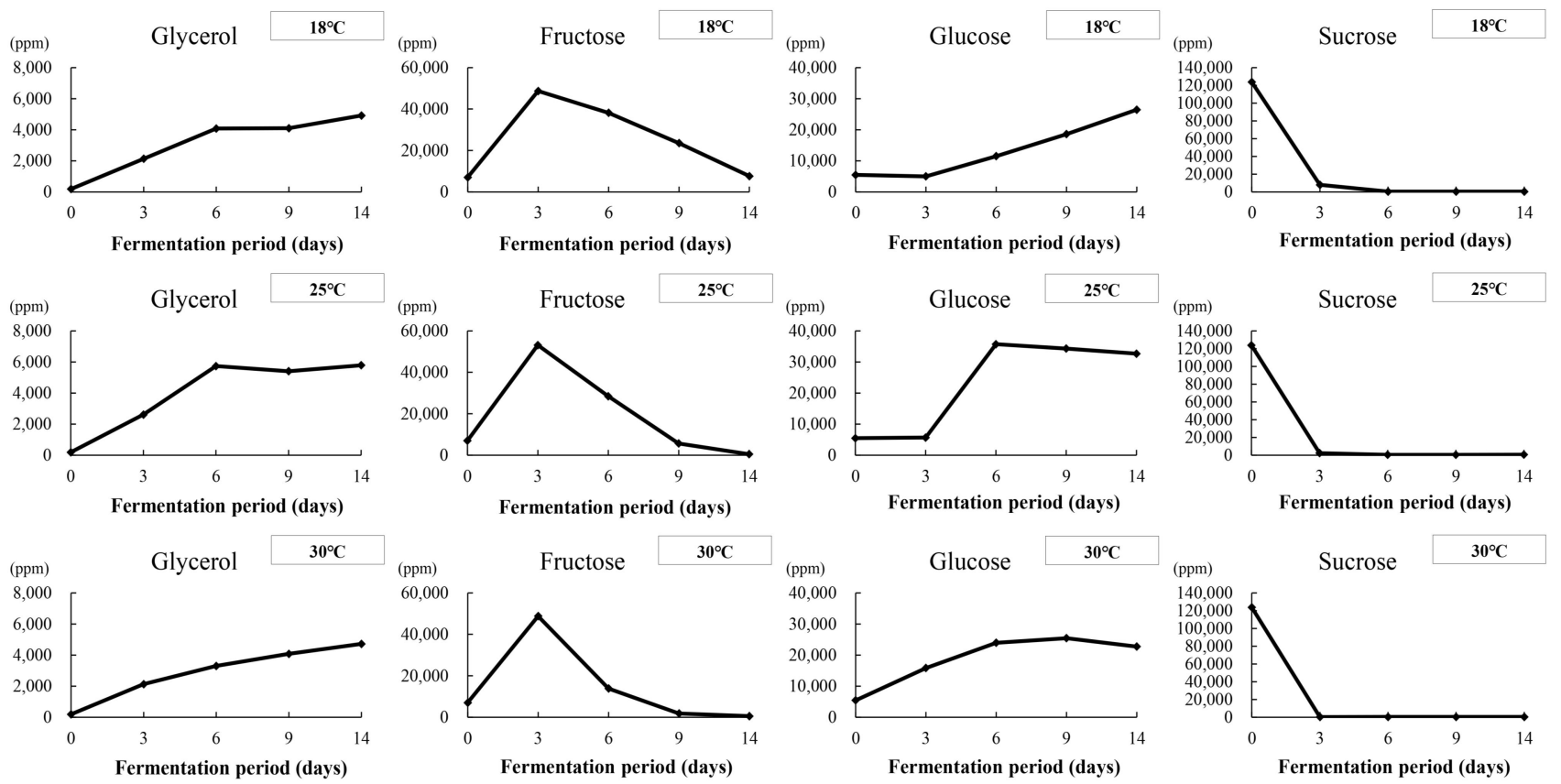

Fig. 6. Changes in free sugar contents of peach wine during fermentation period at various temperatures. 
pH 3

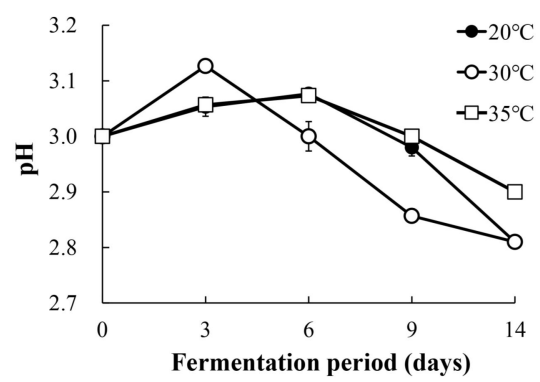

pH 4

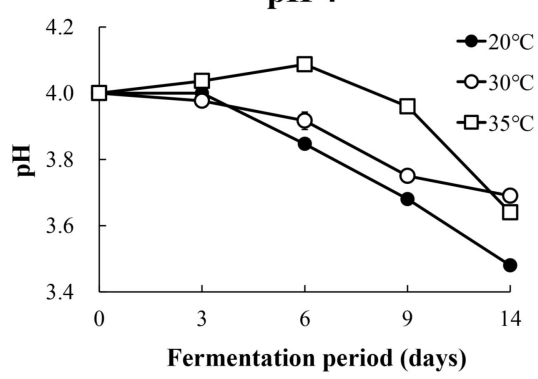

pH 5

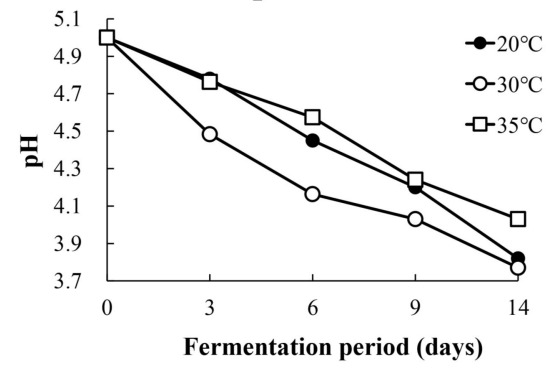

Fig. 7. Changes in $\mathrm{pH}$ of peach vinegar during fermentation period at various initial $\mathrm{pHs}$ and temperatures.

pH 3, $20^{\circ} \mathrm{C}$

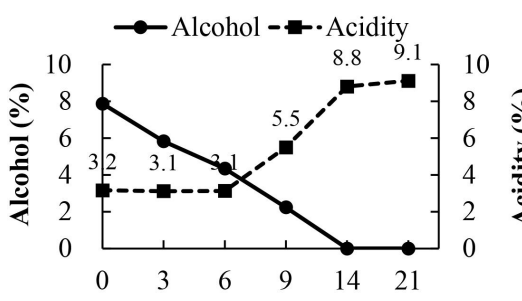

Fermentation period (days)

pH $4,20^{\circ} \mathrm{C}$

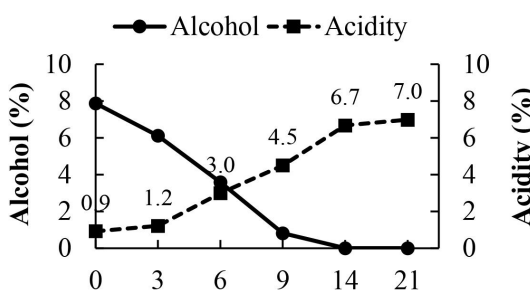

Fermentation period (days)

pH 5, $20^{\circ} \mathrm{C}$

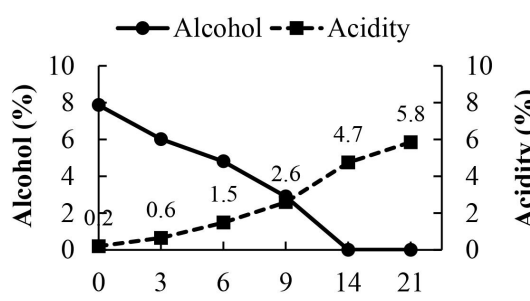

Fermentation period (days)
pH 3, $30^{\circ} \mathrm{C}$

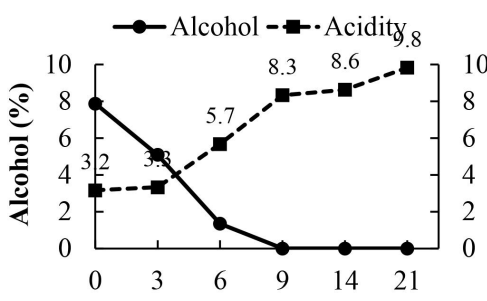

Fermentation period (days)

$\mathrm{pH} 4,30^{\circ} \mathrm{C}$

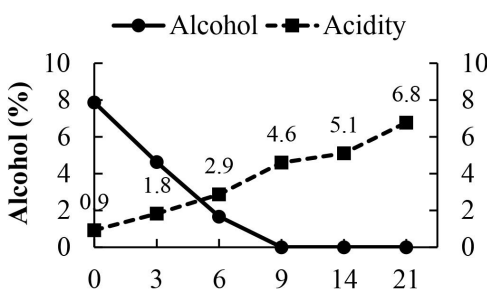

Fermentation period (days)

pH $5,30^{\circ} \mathrm{C}$

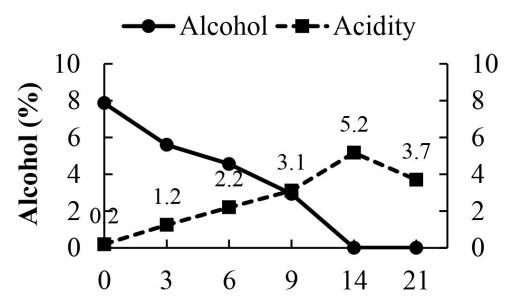

Fermentation period (days)
pH 3, $35^{\circ} \mathrm{C}$

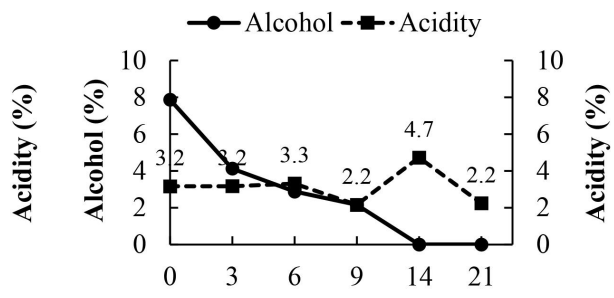

Fermentation period (days)

pH $4,35^{\circ} \mathrm{C}$

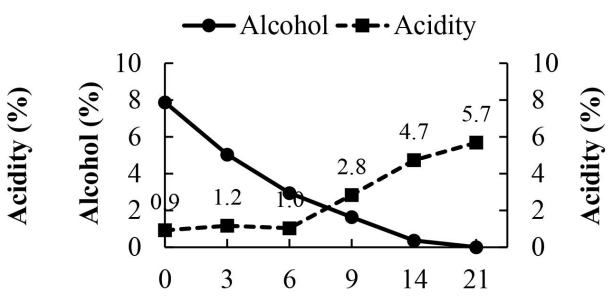

Fermentation period (days)

pH 5, $35^{\circ} \mathrm{C}$

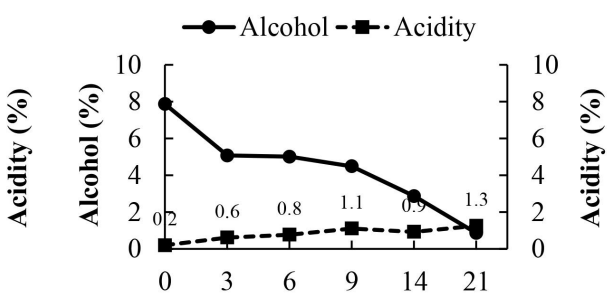

Fermentation period (days)

Fig. 8. Changes in alcohol concentration and acidity of peach vinegar during fermentation period at various pHs and temperatures.

발효식초는 모든 온도 조건에서 초산발효가 진행되었으나 산 도가 $7 \%$ 이하였으며, $\mathrm{pH} 5,20^{\circ} \mathrm{C}$ 에서는 산도가 $6 \%$ 이하로 낮게 측정되었다. Cho 등(2000)의 연구에서 병행복발효를 통 해 $\mathrm{pH}$ 4의 복숭아 즙을 이용해 식초를 제조한 결과, 25 일차
에 최대 $6.64 \%$ 의 산도를 나타내 본 실험의 초기 $\mathrm{pH}$ 4의 결 과와 유사하였다. 반면 초기 $\mathrm{pH}$ 3과 5 의 $35^{\circ} \mathrm{C}$ 처리구에서는 초산발효가 원활히 이루어지지 않았고, 초기 $\mathrm{pH} 4$ 의 $35^{\circ} \mathrm{C}$ 처 리구에서는 0 일차와 비교했을 때 21 일차에 산도가 $4.8 \%$ 증 
가한 것을 확인하였다.

\section{초산 함량 변화}

유기산은 식초의 산미에 영향을 주어 식초 품질에서 매우 중요하며, 특히 초산균에 의해 생성되는 acetic acid는 식초의 주성분으로 알려져 있다(Gullo 등, 2014). 초산균 A. oryzifermentans(KACC19301)로 만든 복숭아 식초의 유기산 분석 결과, 주요 유기산은 acetic acid와 citric acid로 확인되었다. 실험 결과에 따르면 초산 발효가 원활하지 않은 $\mathrm{pH} \mathrm{3,5}$ 의 $35^{\circ} \mathrm{C}$ 처리구를 제외하고 발효기간이 길어질수록 acetic acid 함량이 증가하였다. 초기 $\mathrm{pH} 4,20^{\circ} \mathrm{C}$ 에서 발효시킨 복숭아 식초는 14 일차에 $6,171.3 \mathrm{mg} / 100 \mathrm{~mL}$ 로 가장 acetic acid 함 량이 많았고, 그 다음으로 초기 $\mathrm{pH} 3,20^{\circ} \mathrm{C}$ 에서 발효한 식초

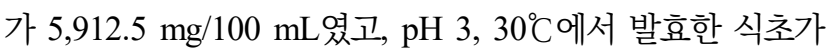
$5,668.4 \mathrm{mg} / 100 \mathrm{~mL}$ 로 측정되었다. 따라서 발효 후기에 acetic acid 함량이 가장 높게 측정된, 초기 $\mathrm{pH} 4$ 의 $20^{\circ} \mathrm{C}$ 에서 발효시키는 것이 초산균 A. oryzifermentans(KACC19301)의 초산 발효에 최적 발효 조건임을 확인하였다(Table 6). 또한 고문헌을 재현한 복숭아 식초의 최대 acetic acid 함량(473.66 $\mathrm{mg} / 100 \mathrm{~mL}$ )과 비교했을 때, 공정 개선된 방법으로 제조한 복숭아 식초의 초산 함량 $(6,171.3 \mathrm{mg} / 100 \mathrm{~mL})$ 이 크게 증가 한 것을 알 수 있었다.

\section{맛 센서 분석}

본 실험에서는 최적 발효 조건인 초기 $\mathrm{pH} 4,20^{\circ} \mathrm{C}$ 에서 발 효시킨 복숭아 식초의 관능적인 특성을 확인하기 위해 맛 센
서 분석을 실시하였다. Joo(2004)의 보고에 따르면 맛 센서는 맛과 관련된 성분을 선택적으로 검출할 수 있는 전자 장치로 관능검사 패널이 파악하기 어려운 분석물의 맛 특성까지 파 악할 수 있어 식품 외에도 의료나 대기환경 등 다양한 분야에 서 이용할 수 있다고 하였다. 맛 센서 분석 결과는 Fig. 9와 같다. 발효가 진행됨에 따라 신맛(AHS)과 감칠맛(NMS)은 증가하고, 단맛(PKS)과 쓴맛(ANS)은 감소하는 것을 확인하 였으며, 초산발효를 통해 acetic acid가 생성되어 산도가 증가 하면서 신맛이 증가하고, 과실 발효 중에 생성된 유기산과 아 미노산이 감칠맛을 증진시킨 것으로 생각된다.

\section{요 약}

본 연구는 고문헌 『임원십육지』에 기록된 복숭아 식초를 현대화하기 위해 개복숭아를 원료로 식초를 제조하고, 제조 공정을 개선하여 발효 조건을 최적화하였다. 먼저 고문헌을 재현한 복숭아 식초는 알코올 발효와 초산발효를 동시에 진 행하며, 14일차에 acetic acid 함량은 $473.66 \mathrm{mg} / 100 \mathrm{~mL}$, lactic acid는 $756.81 \mathrm{mg} / 100 \mathrm{~mL}$ 로 측정되었다. 고산도의 복 숭아 식초를 제조하기 위해서 먼저 알코올 발효능이 우수한 효모와 산 생성능이 높은 균주를 선별하였는데, 이에 따라 효 모 S. cerevisiae $\mathrm{YM} 27$ 과 초산균 A. oryzifermentans ( $\mathrm{KACC}$ 19301)를 선발되었고, 이를 이용하여 복숭아 발효주와 발효 식초를 제조하고, 발효 환경에 따른 품질 특성을 평가하였다. 공정 개선을 위해 주모와 종초를 이용하여 단계적으로 발효 시켰으며, 복숭아 발효주의 알코올 농도를 측정한 결과, 알코

Table 6. Changes in acetic acid of peach vinegar during fermentation period at various initial pH and temperature

(unit: $\mathrm{mg} / 100 \mathrm{~mL}$ )

\begin{tabular}{|c|c|c|c|c|c|c|}
\hline \multirow{2}{*}{$\mathrm{pH}$} & \multirow{2}{*}{$\begin{array}{c}\text { Temperature } \\
\left({ }^{\circ} \mathrm{C}\right)\end{array}$} & \multicolumn{5}{|c|}{ Fermentation period (days) } \\
\hline & & 0 & 3 & 6 & 9 & 14 \\
\hline \multirow{3}{*}{ pH 3} & 20 & $444.9 \pm 10.6^{1 \mathrm{a} 2)}$ & $921.0 \pm 1.9^{\mathrm{b}}$ & $1,088.6 \pm 3.0^{\mathrm{c}}$ & $2,856.5 \pm 19.3^{\mathrm{d}}$ & $5,912.5 \pm 16.5^{\mathrm{b}}$ \\
\hline & 30 & $444.9 \pm 10.6^{\mathrm{a}}$ & $1,015.2 \pm 3.2^{\mathrm{a}}$ & $3,406.2 \pm 4.2^{\mathrm{a}}$ & $5,551.7 \pm 15.0^{\mathrm{a}}$ & $5,668.4 \pm 13.7^{\mathrm{c}}$ \\
\hline & 35 & $444.9 \pm 10.6^{\mathrm{a}}$ & $723.6 \pm 1.2^{\mathrm{d}}$ & $912.2 \pm 4.2^{\mathrm{e}}$ & $693.3 \pm 0.6^{\mathrm{h}}$ & $2,516.6 \pm 2.6^{\mathrm{f}}$ \\
\hline \multirow{3}{*}{$\mathrm{pH} 4$} & 20 & $324.4 \pm 3.5^{\mathrm{b}}$ & $577.3 \pm 1.6^{\mathrm{f}}$ & $1,015.2 \pm 11.6^{\mathrm{d}}$ & $4,376.4 \pm 116.0^{b}$ & $6,171 \cdot 3 \pm 220.3^{\mathrm{a}}$ \\
\hline & 30 & $324.4 \pm 3.5^{\mathrm{b}}$ & $785.9 \pm 0.6^{\mathrm{c}}$ & $2,785.7 \pm 47.1^{\mathrm{b}}$ & $4,289.6 \pm 21.7^{\mathrm{c}}$ & $4,659.1 \pm 39.7^{\mathrm{e}}$ \\
\hline & 35 & $324.4 \pm 3.5^{\mathrm{b}}$ & $577.4 \pm 29.5^{\mathrm{f}}$ & $485.1 \pm 0.5^{\mathrm{i}}$ & $1,095.9 \pm 1.6^{\mathrm{f}}$ & $4,897.2 \pm 24.5^{\mathrm{d}}$ \\
\hline \multirow{3}{*}{$\mathrm{pH} 5$} & 20 & $307.0 \pm 1.2^{\mathrm{c}}$ & $602.9 \pm 1.6^{\mathrm{e}}$ & $817.3 \pm 1.9^{f}$ & $931.1 \pm 9.0^{\mathrm{g}}$ & $4,589.6 \pm 7.9^{\mathrm{e}}$ \\
\hline & 30 & $307.0 \pm 1.2^{\mathrm{c}}$ & $712.0 \pm 0.6^{\mathrm{d}}$ & $785.6 \pm 3.8^{\mathrm{g}}$ & $2,721.5 \pm 5.5^{\mathrm{e}}$ & $4,578.8 \pm 7.7^{\mathrm{e}}$ \\
\hline & 35 & $307.0 \pm 1.2^{\mathrm{c}}$ & $579.4 \pm 1.5^{\mathrm{f}}$ & $548.9 \pm 1.2^{\mathrm{h}}$ & $507.0 \pm 0.3^{\mathrm{i}}$ & $460.0 \pm 5.7^{\mathrm{g}}$ \\
\hline
\end{tabular}

\footnotetext{
${ }^{1)}$ Data values were expressed as mean $\pm \mathrm{SD}$ of triplicate determinations.
}

${ }^{2)}$ Values followed by the same letter are not statistically different by Duncan's multiple range test $(\mathrm{p}<0.05)$. 
(A)

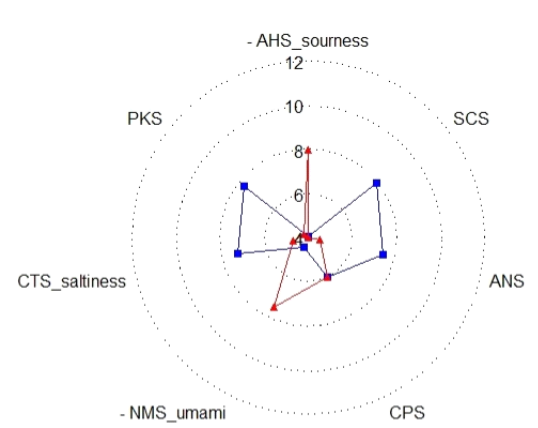

- PV00

(B)

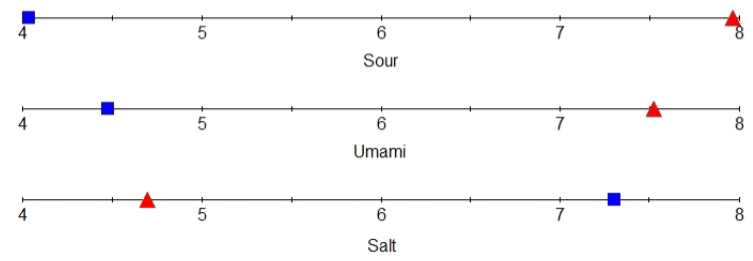

Fig. 9. Changes in organoleptic characteristics of peach vinegar (initial $\mathrm{pH} 4,20^{\circ} \mathrm{C}$ ) by electronic tongue.

Fermentation period; $\mathbf{\square}: 0, \mathbf{\Delta}: 14$.

$\mathrm{A}$, changes in organoleptic characteristics of peach vinegar by electronic tongue; $\mathrm{B}$, changes of intensity scale in organoleptic characteristics of peach vinegar by electronic tongue.

올 발효를 위한 최적 온도는 $25^{\circ} \mathrm{C}$ 로 설정하였다. 발효주의 유 리당 함량은 발효 기간이 길어질수록 glycerol과 glucose 함 량을 꾸준히 증가하였고, fructose는 3 일차까지 증가하다가 그 이후부터 감소하였다. 알코올 농도가 $8 \%$ 내외인 복숭아 발효주의 초기 $\mathrm{pH}$ 를 각각 달리하여 발효시킨 결과, 초기 $\mathrm{pH}$ $3,30^{\circ} \mathrm{C}$ 조건에서 발효된 식초는 21 차에 산도가 0 일차보다 $6.6 \%$ 증가하여 가장 높은 산도 증가량을 보였고, 다음으로는 초기 $\mathrm{pH} 4,20^{\circ} \mathrm{C}$ 조건에서 발효된 식초는 $6.1 \%$ 증가한 것을 확인하였다. 또한 초기 $\mathrm{pH} 4,20^{\circ} \mathrm{C}$ 에서 발효시킨 복숭아 식 초는 14 일차에 $6,171.3 \mathrm{mg} / 100 \mathrm{~mL}$ 로 가장 많은 acetic acid 함량을 나타냈고, 그 다음으로 초기 $\mathrm{pH} 3,20^{\circ} \mathrm{C}$ 와 초기 $\mathrm{pH}$ $3,30^{\circ} \mathrm{C}$ 에서 발효한 식초가 각각 $5,912.5 \mathrm{mg} / 100 \mathrm{~mL}, 5,668.4$ $\mathrm{mg} / 100 \mathrm{~mL}$ 로 측정되었다. 따라서 고산도의 발효 식초를 제 조하기 위한 최적조건으로 초기 $\mathrm{pH}$ 는 4 , 온도는 $20^{\circ} \mathrm{C}$ 로 확립 하였고, ‘도초방'에 따라 재현한 복숭아와 비교했을 때 acetic acid 함량이 크게 증가하였다. 마지막으로 최적 조건에서 발 효한 식초의 맛 센서 분석 결과, 발효기간이 길어질수록 신맛 과 감칠맛이 증가하는 것을 확인하였다. 본 연구의 결과에 따 르면 고산도의 복숭아 식초를 만드는데 필요한 적정 온도 범 위가 넓어 현장에 맞게 적용하기가 용이하며, 종균을 사용하 여 우수하고 균일한 품질의 복숭아 식초를 제조할 수 있을 것으로 기대된다.

\section{감사의 글}

이 논문은 농촌진흥청 농업과학기술개발사업(PJ013418) 의 지원으로 이루어졌으며, 연구비 지원에 감사드립니다.

\section{Conflict of interests}

The authors declare no potential conflict of interest.

\section{ORCID}

Seong-hyun Jeon https://orcid.org/0000-0002-9837-5542 Hee-Min Gwon https://orcid.org/0000-0002-8808-5875

\section{References}

Ahn KH. Atlas to Canons of Primitive-Modern Oriental Medicine. Seowondang, Seoul, Korea, p 205-206 (1980)

Asai T, Shoda K. The taxonomy of acetobacter and allied oxidative bacteria. J Gen Appl Microbiol, 4, 289-311 (1958)

Cho JW, Kim IS, Kim MK, Lee YK, Kim SD. Characteristics of peach vinegar by parallel complex fermentation. Korean J Postharvest Sci Technol, 7, 89-93 (2000)

Cho KH, Nam EY, Bae KM, Shin IS, Kim SH, Kim HR, Chung KH. Analysis of genetic diversity among wild peach germplasms using DNA markers. Kor J Breed Sci, 44, 588-596 (2012)

Gullo M, Verzelloni E, Canonico M. Aerobic submerged fermentation by acetic acid bacteria for vinegar production: Process and biotechnological aspects. Process Biochem, 49, 1571-1579 (2014)

Hwang SJ, Cho JH, Cho JG, Shin SH, Suh HK. Changes in external auditory canal epithelium $\mathrm{pH}$ following vinegar irrigation and its effectiveness in external otitis patients. J Clinical Otolaryngol, 12, 203-207 (2001)

Jain VK, Divol B, Prior BA, Bauer FF. Elimination of glycerol and replacement with alternative products in ethanol fermentation by Saccharomyces cerevisiae. J Ind Microbiol Biotechnol, 38, 1427-1435 (2011)

Jang SY, Woo SM, Kim MY, Jin YJ, Park HS, Choi JE, Jeong YJ. Domestic consumer research for the development of naturally fermented vinegar. Food Science and 
Industry, 48, 37-44 (2015)

Joo HH. Applications of Electronic Noses and Tongues in Food Analysis. Report of KISTI. KISTI, 10985, 587-604 (2004)

Jung KM, Kim SH, Jeong YJ, Choi MA. Quality characteristics and antioxidant effect of sugar preserved wild peach (Prunus persica L.) juice by enzymatic treatment. Culi Sci Hos Res, 23, 25-33 (2017a)

Jung KM, Choi MA, Park SI. Effect of oligosaccharides on quality characteristics and antioxidant activities of Prunus persica Batsch var. davidiana Max. preserved in sugar. Culi Sci Hos Res, 23, 163-172 (2017b)

Jung KI, Jung HN, Ha NY, Choi YJ. Physiochemical properties, and antioxidative and alcohol-metabolizing enzyme activities of nectarine vinegar. J Life Sci, 28, 1193-1200 (2018a)

Jung KM, Lee YS, Kim JW, Soel JM, Jung YH, Kim SR. Low-temperature alcoholic fermentation for the production of high quality vinegar using peach. KSBB J, 33, 95-103 (2018b)

Kim DH. Studies on the production of vinegar from fig. J Korean Soc Food Sci Nutr, 28, 53-60 (1999)

Kim HS. Effects of the Prunus persica Batsch var. davidiana Max. extract on the lipid compositions and enzyme activities in hyperlipidemic rats. Korean J Food Nutr, 17, 328-336 (2004)

Kim HS. Effects of the feral peach (Prunus persica Batsch var. davidiana Max.) extract on the lipid compositions and blood pressure level in spontaneously hypertensive rats. J Life Sci, 16, 1071-1079 (2006)

Kim DM, Kim KH, Choi IJ, Yook HS. Composition and physicochemical properties of unripe Korean peaches according to cultivars. J Korean Soc Food Sci Nutr, 41, 221-226 (2012)

Kim MS, Hong YA, Yeo SH, Baek SY, Yun HJ, Rhee Ch, Kim KP, Park HD. Environmental resistance of indigenous Saccharomyces cerevisiae with tolerance to potassium metabisulfite at the microbial succession stage of fermenting Campbell Early grape. Korean J Food Preserv, 20, 886-893 (2013)

Kondo S, Tayama K, Tsukamoto Y, Ikeda K, Yamori Y. Antihypertensive effects of acetic acid and vinegar on spontaneously hypertensive rats. Biosci Biotechnol Biochem, 65, 2690-2694 (2001)

Lee YC, Lee GY, Kim HC, Park KB, Yoo YJ, Ahn PU, Choi CU, Son SH. Production of high acetic acid vinegar using two stage fermentation. Kor J Appl Microbiol Biotechnol, 20, 663-667 (1992)

Lee SW, Kwon JH, Yoon SR, Woo SM, Jang SY, Yeo SH, Choi JH, Jeong YJ. Quality characteristics of brown rice vinegar by different yeasts and fermentation condition. J Korean Soc Food Sci Nutr, 39, 1366-1372 (2010)

Lim EJ, Cha GH. Study on manufacturing of vinegar through literatures of the Joseon Dynasty. Korean J Food Culture, 25, 680-707 (2010)

Oh KJ, Kim MJ, Han JS, Ji EH, Kim AJ. Comparative biological properties of Prunus davidiana fruits according to harvest month. Korean J Food Nut, 28, 643-649 (2015)

Oh YA, Kim SD, Kim KH. Effect of addition of water extract of pine needle on tissue of kimchi. J Korean Soc Food Sci Nutr, 27, 461-470 (1998)

Park HJ, Choi WI, Park JM, Jeong CW, Kim SD, Yoon HS. Brewing and quality characteristics of new grape cultivar 'Okrang' wine in fermentation process. J Korean Soc Food Sci Nutr, 46, 622-629 (2017)

Rho HI, Chang EH, Joeng ST, Jahng KY. Characteristics of fermentation and wine quality. Korean J Food Preserv, 15, 317-324 (2008)

Shin EJ, Kang SM. The effect of complex diet of collagen and vinegar on improvement of skin on the back of hands. Asian J Beauty Cosmetol, 10, 371-379 (2012)

Sim KC, Lee KS, Kim DH, Ryu IH, Lee JS. Studies on the acid tolerance of Acetobacter sp. isolated from persimmon vinegar. Korean J Food Sci Technol, 33, 574-581 (2001) 